\title{
APLIKASI FORECASTING PENJUALAN BAHAN BANGUNAN MENGGUNAKAN METODE TREND MOMENT (STUDI KASUS DI UD. HASIL BUMI)
}

\author{
Mohamad Agung Firmansyah, Agung Panji Sasmito, Hani Zulfia Zahro' \\ Program Studi Teknik Informatika S1, Fakultas Teknologi Industri \\ Institut Teknologi Nasional Malang, Jalan Raya Karanglo km 2 Malang, Indonesia \\ agungfirman.af21@gmail.com
}

\begin{abstract}
ABSTRAK
Toko UD. Hasil Bumi memiliki permasalahan mengenai belum adanya sebuah sistem untuk memprediksi penjualan bahan bangunan dari masa ke masa. Dalam hal ini strategi permasalahan yang tepat untuk mengatasinya adalah menggunakan Forecasting dengan metode Trend Moment yang berbasis website. Tujuan penelitian ini adalah menghasilkan sebuah aplikasi Forecasting penjualan bahan bangunan yang dapat membantu toko UD. Hasil Bumi untuk memprediksi penjualan bahan bangunan dari masa ke masa dengan berbasis web dan menerapkan metode Trend Moment pada aplikasi Forecasting penjualan bahan bangunan yang dapat membantu toko UD. Hasil Bumi dalam memprediksi penjualan untuk tahun yang akan datang. Penelitian ini menggunakan data penjualan toko UD. Hasil Bumi pada tahun 2018 sampai dengan tahun 2019. Penelitian ini menggunakan metode Trend Moment yang digunakan untuk memprediksi penjualan diwaktu yang akan datang dengan perhitungan statistika dan matematika. Hasil dari perhitungan rata - rata persentase error pada hasil Forecasting penjualan bahan bangunan keseluruhan di UD. Hasil Bumi yaitu 36.78770742 \%. Hasil penelitian ini menunjukkan adanya perkembangan dari aplikasi Forecasting penjualan bahan bangunan dengan metode Trend Moment dan dapat dijalankan dengan baik berdasarkan hasil pengujian metode Black-Box dapat dijalankan sesuai luaran yang diharapkan.
\end{abstract}

\section{Kata Kunci : UD. Hasil Bumi, Forecasting, Penjualan, Trend Moment}

\section{PENDAHULUAN}

UD. Hasil Bumi adalah sebuah toko yang menjual berbagai bahan bangunan meliputi semen (semen gresik dan semen tiga roda), pasir (pasir lumajang dan pasir biasa), batu (batu belah dan batu krikil), bata ringan, besi (ukuran diameter besi 6,8 , 10 dan 12), asbes dan sebagainya yang terletak di Desa Tanjungarum, Kecamatan Sukorejo, Kabupaten Pasuruan.

Salah satu permasalahan yang dihadapi oleh UD. Hasil Bumi adalah belum adanya sistem untuk memprediksi penjualan bahan bangunan dari masa ke masa oleh UD. Hasil Bumi tersebut. Strategi yang digunakan untuk permasalahan pengelolahan penjualan bahan bangunan di toko UD. Hasil Bumi adalah Forecasting. Forecasting merupakan kegiatan memperkirakan sesuatu yang akan terjadi pada masa akan mendatang dengan data yang pada masa lampau dan akan memprediksi ke masa yang akan mendatang dengan sesuatu yang berbentuk matematis [7]. Karena hal tersebut sangat berpengaruh terhadap keputusan pemilik toko untuk menentukan jumlah stok barang yang harus disediakan oleh UD. Hasil Bumi.

Salah satu metode Forecasting yang akan digunakan pada permasalahan di UD. Hasil Bumi adalah dengan metode Trend Moment. Metode Forecasting Trend Moment adalah salah satu cara perhitungan matematika dan statistika tertentu untuk mengetahui sesuatu fungsi garis lurus sebagai pengganti garis terputus yang dibentuk oleh data penjualan atau historis perusahaan. Dengan demikian, pengaruh unsur subyektif dapat dihindarkan. Keunggulan metode Trend Moment ini dibandingkan metode Forecasting yang lain terletak pada parameter $\mathrm{X}$ atau indeks waktu yang dipakai, apakah data yang digunakan data historis berjumlah genap atau ganjil tidak ada perbedaan. Karena parameter $\mathrm{X}$ dimulai dengan nilai 0 sebagai nilai awal [13].

Dengan dibuatnya aplikasi tersebut, diharapkan pada toko UD. Hasil Bumi dapat memperkirakan target penjualan yang ingin dicapai serta dapat menentukan produk yang paling tepat untuk memaksimalkan keuntungan dalam penjualan. Aplikasi berbasis website ini bersifat multiplatform. Sehingga owner atau pemilik toko UD. Hasil Bumi dapat menjalankan aplikasi berbasis web dimanapun tanpa harus melakukan penginstalan dan tidak memerlukan spesifikasi komputer yang tinggi.

\section{TINJAUAN PUSTAKA}

\subsection{Penelitian Terdahulu}

Pada penelitian yang dilakukan oleh Santi dan Saputra yang berjudul "Prediksi Jumlah Permintaan Telur Ayam Menggunakan Metode Trend Moment". Penelitian ini bertujuan untuk memprediksi jumlah permintaan telur ayam dinilai sebagai suatu solusi yang mampu menyelesaikan permasalahan tersebut. Prediksi permintaan jumlah terlur ayam ini dihitung menggunakan metode Trend Moment, yang dimana hasil prediksi cenderung meningkat berdasarkan data sebelumnya (historis). Hasil prediksi permintaan telur tersebut menghitung data jumlah penjualan telur ayam dengan bulan yang sama pada 2 tahun 
sebelumnya untuk mendapatkan hasil prediksi jumlah permintaan telur ayam yang akan mendatang. Pengujian menggunakan data hasil prediksi pada bulan September ditahun 2017 sampai pada bulan Juli ditahun 2018. Hasil dari pengujian memiliki tingkat keakuratan yang tinggi berdasarkan nilai rata-rata kemungkinan kesalahan sebesar 1,4\%[9].

Pada penilitian yang dilakukan oleh Frans, Orisa dan Wibowo yang berjudul "Prediksi Penjualan Kayu Lapis Di Cv Diato Wood Sejahtera Dengan Metode Trend Moment Berbasis Web". Penelitian ini bertujuan untuk prediksi penjualan yang akan dijadikan sebagai dasar peningkatan penjualan pada periode selanjutnya. Metode Trend Moment adalah salah satu cara perhitungan statistika dan matematika tertentu untuk mengetahui fungsi garis lurus sebagai pengganti garis putus-putus yang dibentuk oleh data historis perusahaan. Penelitian menggunakan sampel data real pada data penjualan kayu lapis di cv.diato wood sejahtera 2 tahun sebelumnya yaitu pada tahun 2017 dan tahun 2018 sebagi nilai perbandingan[3].

Pada penelitian yang dilakukan oleh Sumaryono yang berjudul "Penerapan Metode Trend Moment Dalam Forecast Penjualan Beton Readymix Di Pt. X, Mojokerto" Penelitian ini bertujuan untuk mengidentifikasi dan menganalisis hasil ramalan penjualan beton ready mix dengan metode ramalan Trend Moment dan merancang aplikasi peramalan penjualan beton ready mix dengan menggunakan metode Trend Moment untuk mengatasi kerugian dan tidak tercapainya target perusahaan. Hasil dari peramalan penjualan beton readymix PT. X dengan metode Trend Moment di bulan Januari 2015 yaitu cenderung meningkat atau mengalami Trend Positif dibandingkan dengan penjualan tahun lalu[11].

Pada penelitian yang dilakukan oleh Fuad dan Sulistiono yang berjudul "Prediksi Penjualan Kerudung Rabbani Di Griya Muslim Store Dukun Gresik Dengan Trend Moment" Penelitian ini bertujuan agar sebuah butik dapat bersaing dalam dunia bisnis. Peran teknologi untuk memahami dan mempunyai sesuatu kemampuan dalam memprediksi keadaan bisnis di masa yang akan datang sangat dibutuhkan. Metode Trend Moment merupakan metode yang digunakan untuk Forecast atau prediksi penjualan, yang nanti akan dijadikan sebagai dasar peningkatan penjualan pada periode yang akan datang. Metode Trend Moment menggunakan cara perhitungan statistika dan matematika tertentu untuk menentukan fungsi garis lurus sebagai pengganti garis putus-putus yang dibentuk oleh data historis perusahaan[4].

\subsection{Dasar Teori}

\subsubsection{Bahan Bangunan}

Bahan bangunan adalah bahan pokok maupun alat yang diperlukan untuk membangun suatu bangunan tertentu. Bahan bangunan termasuk berbagai jenis kayu, pasir, batu, batu bata, besi, semen dan lain-lain. Alat yang digunakan ialah seperti palu, tang, mesin bor, gergaji, skop pasir dan lain lain.

\subsubsection{UD. Hasil Bumi}

UD. Hasil Bumi adalah industri perdagangan material berbagai bahan bangunan meliputi semen (semen gresik dan semen tiga roda), pasir (pasir lumajang dan pasir biasa), batu (batu belah dan batu krikil), bata ringan, besi (ukuran diameter besi 6, 8, 10 dan 12), asbes dan sebagainya yang beralamat di jalan. Indrokilo No.1, Dusun. Ngemplak, Desa. Tanjungarum, Kecamatan. Sukorejo, Kabupaten. Pasuruan.

\subsubsection{Forecasting (Prediksi)}

Forecasting adalah sebuah prediksi tentang suatu hal yang salah satunya mengenai penjualan data di masa lampau yang digunakan untuk keperluan estimasi data diwaktu yang akan datang[5]. Forecasting adalah bagian terpenting pada setiap perusahaan ataupun organisasi bisnis dalam pengambilan keputusan manajemen[5].

Forecasting dapat menjadi dasar bagi perencanaan jangka pendek, menengah maupun jangka panjang pada sesuatu industri perdagangan. Forecasting merupakan dugaan atau perkiraan mengenai terjadinya suatu kejadian atau peristiwa di waktu yang akan mendatang[5]. Perencanaan yang efektif baik untuk jangka panjang maupun pendek bergantung pada prediksi permintaan untuk produk perusahaan tersebut. Peramalan adalah kegiatan memprediksi sebuah variabel berdasarkan nilai yang diketahui dari variabel tersebut. Ada dua macam metode yaitu metode kualitatif dan metode kuantitatif. Pada metode kualitatif hanya menggunakan intuisi saja, tanpa menggunakan pendekatan matematis maupun statistik. Situasi, kondisi, dan pengalaman peramal sangat mempengaruhi pada hasil ramalan.

\subsubsection{Data Mining}

Data mining adalah untuk menemukan, menggali, atau menambang pengetahuan dari data atau informasi yang di miliki [12]. Secara teknis, data mining adalah proses yang memanfaatkan teknik teknik statistic, matematika, dan kecerdasan buatan untuk mengekstrak dan mengindentifikasi informasi dan knowledge selanjutnya pola-pola yang berasal dari sekumpulan data yang sangat besar. Kebanyakan literatur mendefinisikan data mining sebagai proses yang rumit untuk mengidentifikasi pola-pola yang baru terhadap data yang disimpan di dalam database yang terstruktur [1].

\subsubsection{Trend Moment}

Metode Trend Moment adalah sebuah sistem peramalan penjualan yang dapat membantu meminimalkan biaya dalam menyuplai barang yang akan dijual, karena dengan mengetahui beberapa penjualan pada periode yang akan datang, perusahaan 
dapat menyuplai barang secara tidak berlebihan [5]. Dalam penerapan metode Trend Moment dapat dilakukan dengan menggunakan data historis dari satu variabel, adapun persamaan yang digunakan dalam penyusunan dari metode ini [9].

Persamaan Trend dengan metode Moment mempunyai 3 persamaan yaitu persamaan 1 digunakan untuk menghitung nilai Trend atau variabel yang akan diramalkan. Persamaan 2 yaitu digunakan untuk menghitung slope atau koefisien pada garis Trend. Persamaan 3 digunakan untuk menghitung bilangan konstan [8]. Kelebihan dari metode Trend Moment dibandingkan dengan metode lainnya terletak pada penggunaan parameter $\mathrm{X}$ atau indeks waktu yang dipakai, sehingga tidak ada perbedaan apakah data yang dipakai merupakan data historis berjumlah genap ataukah ganjil [9]. Persamaan Trend dengan menggunakan metode Trend Moment pada persamaan (1).

$$
\hat{Y}=a+b X
$$

Dimana Variabel:

$\hat{Y}$ : Nilai trend atau variabel yang akan prediksi atau hasil prediksi

a : Bilangan konstanta

b : Slope atau kemiringan garis Trend

$\mathrm{X} \quad$ : Indeks waktu (Dimulai dari

$0,1,2, \ldots . . n)$

Mencari nilai a dan $\mathrm{b}$ dengan cara penyelesaian menggunakan dua persamaan normal. Adapun persamaan untuk mencari nilai $b$ [9] pada persamaan (2).

$$
b=\frac{n(\Sigma X Y)-(2 X)([X)}{n\left(\Sigma X^{2}\right)-(\Sigma X)^{2}}
$$

Dimana Variabel:

¿Y : Jumlah dari data penjualan

$\mathrm{\Sigma X}$ : Jumlah dari periode waktu

EXY: Jumlah dari data penjualan dikali dengan periode waktu

$\Sigma X^{2}$ : Jumlah dari data periode waktu yang dikuadratkan

$n$ : Banyaknya pengamatan

Mencari nilai a [9] pada persamaan (3).

$$
a=\frac{\Sigma Y-b(\Sigma X)}{n}
$$

Dimana variabel:

¿Y : Jumlah dari data penjualan

b : Nilai hasil perhitungan persamaan $b$

EX : Jumlah dari periode waktu

$n$ : Banyaknya pengamatan

\subsubsection{Website}

Website adalah sesuatu kumpulan halaman halaman yang digunakan untuk menampilkan informasi teks, gambar diam atau gerak, animasi, suara, atau gabungan dari semuanya dengan bersifat statis maupun dinamis yang berbentuk satu rangkaian dengan bangunan yang saling terkait, yang pada masing-masing dihubungkan dengan jaringanjaringan pada halaman[2]. Hubungan antara halaman pada web dengan halaman yang lainnya disebut hyperlink, teks yang dijadikan sebagai media penghubung adalah hypetext[2].

Ada beberapa jenis web berdasarkan sifat atau stylenya yaitu Website Dinamis, yang dimana sebuah website yang menyediakan content atau isi yang selalu berubah-ubah setiap saat. Bahasa pemrograman yang digunakan antara lain $P H P, A S P, N E T$ dan memanfaatkan database MySQL. Misalnya website www.artikel.com, www.detik.com, www.tecnomobile.co.cc, dan lain-lain. Sedangkan website statis, merupakan website yang contentnya sangat jarang diubah. Misalnya web profile organisasi, dan lain-lain[2].

\subsubsection{Database $M y S q l$}

MySQL adalah database yang bersifat open source. Banyak digunakan sebagai sumber data dan pengolahan data untuk membangun aplikasi berbasis web. $M y S Q L$ merupakan kumpulan data atau informasi yang kompleks, data-data tersebut disusun menjadi beberapa kelompok dengan tipe data yang sejenis disebut table/entity, di mana setiap datanya dapat saling berhubungan satu sama lain atau dapat berdiri sendiri, sehingga mudah diakses [10].

MySQL sebuah implementasi dari sebuah sistem manajemen basisdata relasional (RDBMS) yang dapat didistribusikan secara gratis dibawah lisensi $G P L$ (General Public License). Pengguna dapat secara bebas menggunakan $M y S Q L$, dengan beberapa batasan perangkat lunak tersebut tidak boleh dijadikan produk yang bersifat komersial. MySQL merupakan turunan salah satu konsep utama dalam basisdata yang telah ada sebelumnya SQL (Structured Query Language). SQL adalah konsep pengoperasian basisdata, terutama untuk memilih atau menyeleksi dan memasukkan data, yang memungkinkan pengoperasian data dapat dikerjakan dengan mudah secara otomatis [6].

\subsubsection{HTML}

HTML adalah dasar terbentuknya web. Dan kode-kode HTML tersebut, yang sifatnya universal tadi, akan diterjemahkan oleh komputer pengguna dengan bentuk tampilan yang sama baik itu teks, grafik atau bahkan multimedia. Sebuah program atau aplikasi atau sistem yang memberikan layanan yang berisi sekelompok kode-kode program berbasis teks, baik sederhana atau rumit dan bersifat universal [10].

\subsubsection{PHP}

PHP merupakan script untuk pemrograman script web server-side, script yang membuat dokumen HTML secara on the fly, maksudnya dokumen HTML yang dihasilkan dari suatu aplikasi bukan dokumen HTML yang dibuat dengan menggunakan editor teks atau editor HTML. PHP adalah Personal Home Page, Dibuat pertama kali oleh Rasmus Lerdoff. PHP, awalnya merupakan program yang dikhususkan untuk menerima input melalui form yang ditampilkan dalam browser web. 
Software ini disebarkan dan dilisensikan sebagai perangkat lunak Open Source [10].

\section{METODE PENELITIAN}

\subsection{Metode Trend Moment}

Metode yang digunakan pada penelitian ini adalah Research and Development dengan tujuan mengembangkan aplikasi Forecasting penjualan bahan bangunan menggunakan metode Trend Moment. Aplikasi ini dikembangkan berdasarkan hasil analisis permasalahan yang ada di toko UD. Hasil Bumi untuk memprediksi target penjualan yang akan datang berdasarkan data penjualan sebelumnya, serta bertujuan untuk meningkatkan kualitas pelayanan yang ada di toko UD. Hasil bumi.

Penggunaan metode Trend Moment diperlukan data penjualan pada bulan Januari tahun 2018 sampai bulan Desember tahun 2019 untuk melakukan Forecasting penjualan pada toko UD. Hasil Bumi. Pada metode Trend Moment terdapat varibel Y yang merupakan data penjualan perbulan pada toko UD. Hasil Bumi, variabel $\mathrm{X}$ merupakan periode waktu, variabel XY merupakan hasil dari data penjualan dikali dengan periode waktu, dan variabel $X^{2}$ merupakan periode waktu yang dikuadratkan. Selanjutnya untuk menentukan nilai hasil prediksi pada bulan Januari tahun 2020 sampai Desember 2021 menggunakan metode Trend Moment dengan rumus persamaan $1 . \hat{Y}=a+b(X)$ untuk menghitung nilai Trend atau variabel yang akan diramalkan. Untuk mendapatkan nilai hasil prediksi $\hat{Y}$, ditentukan terlebih dahulu perhitungan slope atau koefisien garis Trend dengan rumus persamaan $2 . b=\frac{n(\Sigma X Y)-(\Sigma X)(\overline{Z Y})}{n\left(\Sigma X^{2}\right)-(\Sigma X)^{2}}$ yang dimana variabel $\mathrm{n}$ merupakan jumlah data pengamatan, variabel $\Sigma X Y$ hasil penjumlahan dari data penjualan dikali dengan periode waktu keseluruhan, variabel $\mathrm{\Sigma X}$ hasil penjumlahan dari data periode waktu keseluruhan, variabel $\mathrm{ZY}$ hasil penjumlahan dari data penjualan keseluruhan pada toko UD. Hasil Bumi, dan variabel $\Sigma X^{2}$ hasil penjumlahan dari data periode waktu yang dikuadratkan. Selanjutnya menghitung bilangan konstan dengan rumus persdamaan 3. $a=\frac{\mathrm{EY}-\mathrm{b}(\mathrm{zX})}{n}$ yang dimana variabel $\mathrm{ZY}$ hasil penjumlahan dari data penjualan keseluruhan pada toko UD. Hasil Bumi, variabel b merupakan hasil perhitungan mencari slope atau koefisien garis Trend, variabel $\mathrm{EX}$ hasil penjumlahan dari data periode waktu keseluruhan dan variabel $\mathrm{n}$ merupakan jumlah data pengamatan.

Setelah mendapatkan nilai persamaan 2 dan 3, maka nilai hasil Forecasting dari bulan Januari 2020 sampai bulan Desember 2021 dapat di hitung nilai Trend atau variabel yang akan diramalkan dengan rumus persamaan $1 . \hat{Y}=a+b(X)$ yang dimana variabel $\mathrm{X}$ pada rumus $\hat{Y}$ tersebut merupakan periode waktu Forecasting.

\subsection{Diagram Blok Sistem}

Pada Diagram Blok Sistem Admin dapat dijelaskan bahwa admin terhubung ke internet terlebih dahulu kemudian mengakses website untuk login. Pada Gambar 1 bahwa admin dapat input data kedalam database, untuk melakukan prediksi admin dapat masuk ke halaman prediksi untuk melakukan perhitungan menggunakan metode Trend Moment. Hasil perhitungan adalah informasi prediksi yang dapat diakses oleh admin.

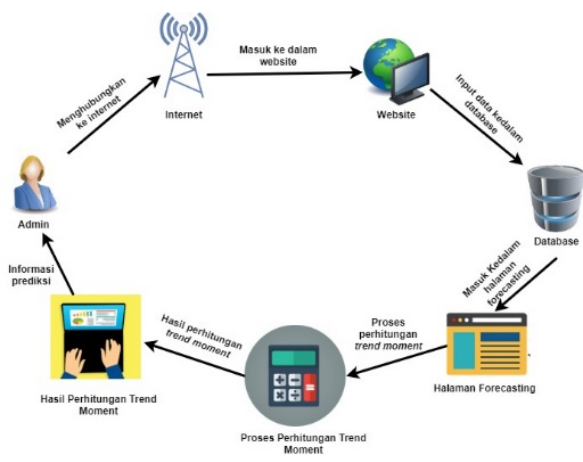

Gambar 1. Diagram Blok Sistem

\subsection{Flowchart Sistem}

Flowchart aplikasi Forecasting penjualan bahan bangunan menunjukkan proses urutan sistem dari awal sampai akhir. Pada Gambar 2.

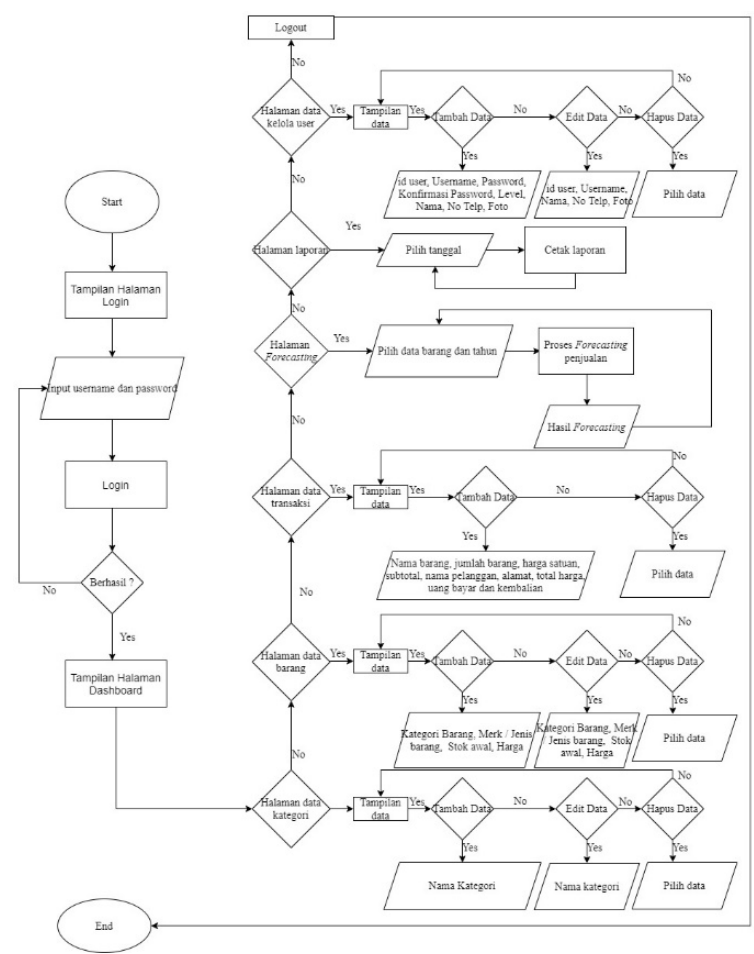

Gambar 2. Flowchart Sistem

Berdasarkan pada Gambar 2. proses pertama kali adalah halaman login admin yang di mana harus memasukkan username dan password. Admin yang berhasil masuk ke sistem terdapat beberapa menu yaitu halaman dashboard, data kategori, data barang, 
data transaksi, Forecasting, laporan dan data Kelola user.

\subsection{Flowchart Metode Trend Moment}

Flowchart Metode Trend Moment menunjukkan alur kerja atau proses urutan sistem dari metode Trend Moment yaitu pada Gambar 3.

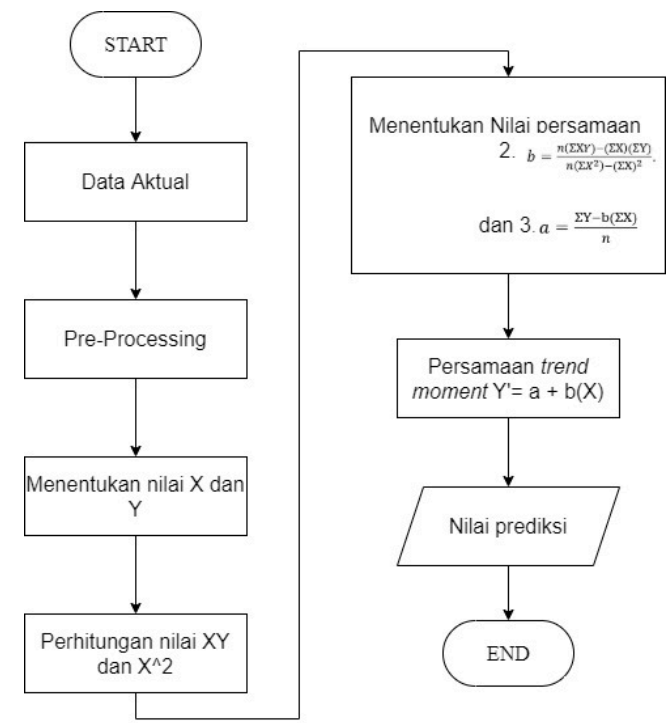

Gambar 3. Flowchart metode

Berdasarkan pada Gambar 3. Proses yang pertama kali proses pengumpulan data aktual yaitu data penjualan, dari data aktual ke proses preprocessing mengeleminasi variabel yang tidak dibutuhkan selanjutnya menentukan nilai X dan Y di mana $\mathrm{X}$ merupakan periode, dan $\mathrm{Y}$ merupakan banyaknya penjualan bahan bangunan ke proses selanjutnya perhitungan nilai XY yang merupakan hasil dari data penjualan dikali dengan periode waktu dan nilai $\mathrm{X}^{\wedge} 2$ merupakan periode waktu yang dikuadratkan. Selanjutnya menetukan nilai persamaan 2 dan 3 sehingga didapat persamaan Trend. Dari hasil variabel $Y^{\prime}$ merupakan hasil nilai prediksi yang diramalkan.

\section{HASIL DAN PEMBAHASAN}

\subsection{Halaman Login}

Pada halaman login diberikan hak akses admin untuk login. Admin harus menginputkan username dan password untuk dapat masuk ke halaman utama admin.

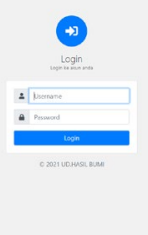

Gambar 4. Halaman Login

\subsection{Halaman Dashboard}

Pada halaman dashboard terdapat menu sidebar untuk masuk ke halaman data kategori, data barang, data transaksi, Forecasting, laporan dan data kelola user. Dan halaman admin adalah halaman yang pertama kali diakses oleh admin.

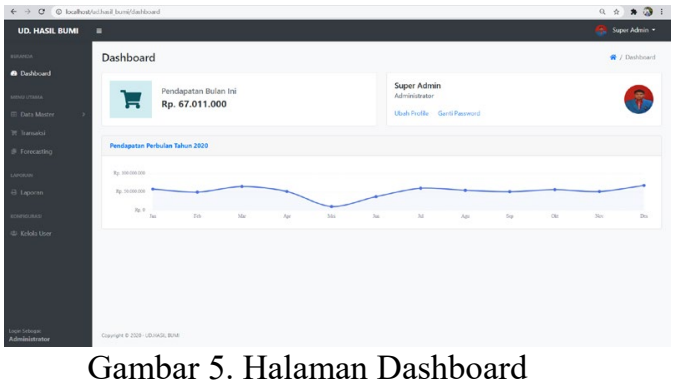

\subsection{Halaman Data kategori}

Pada tampilan halaman kategori terdapat data kategori barang dengan demikian admin dapat melihat, menambahkan, mengubah, menghapus data kategori.

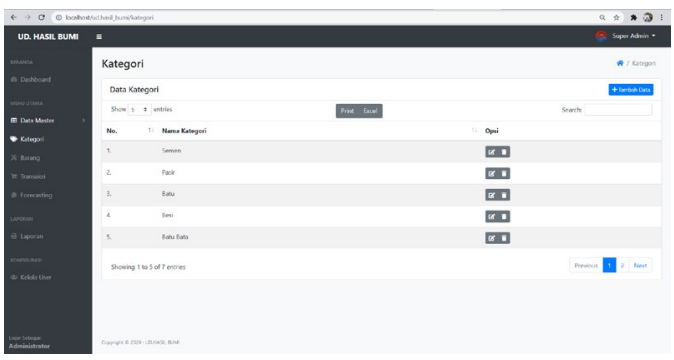

Gambar 6. Halaman Data Kategori

\subsection{Halaman Data Barang}

Pada tampilan halaman Barang terdapat data barang dengan demikian admin dapat melihat, menambahkan, mengubah, menghapus data barang.

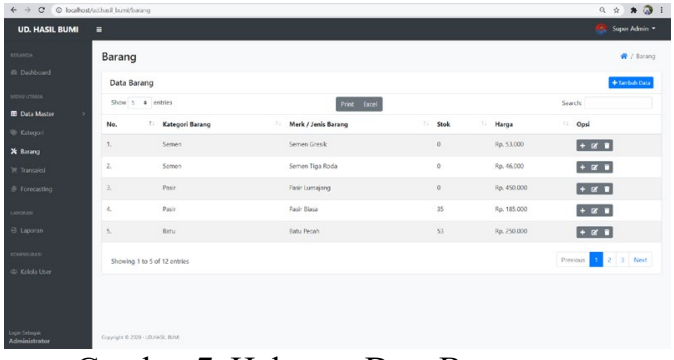

Gambar 7. Halaman Data Barang

\subsection{Halaman Data Transaksi}

Pada tampilan halaman transaksi terdapat data transaksi penjualan bahan bangunan dengan demikian admin dapat melihat, menambahkan, menghapus data transaksi penjualan bahan bangunan. 


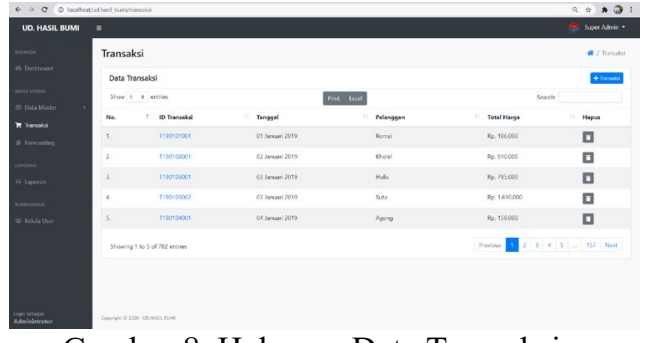

Gambar 8. Halaman Data Transaksi

\subsection{Halaman Forecasting}

Pada tampilan halaman Forecasting admin dapat memprediksi penjualan dengan klik button hitung akan menampilkan perhitungan metode Trend Moment dan grafik.

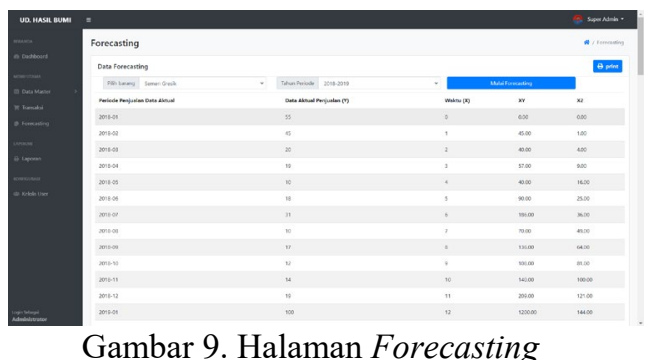

\subsection{Halaman Laporan}

Pada tampilan halaman laporan admin dapat membuat laporan transaksi penjualan dengan memilih dimulai tanggal sampai tanggal berapa transaksi yang akan dicetak.

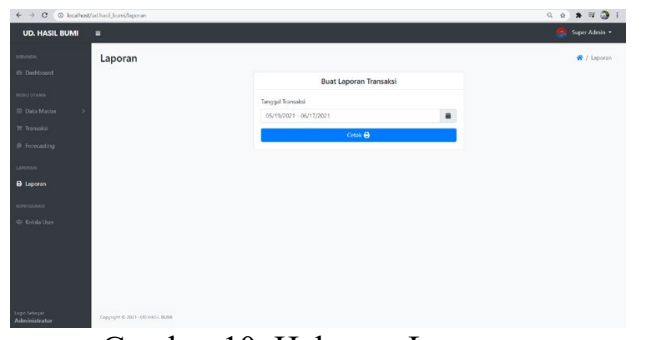

Gambar 10. Halaman Laporan

\subsection{Halaman Data Kelola User}

Pada tampilan halaman kelola user terdapat data admin dengan demikian admin dapat melihat, menambahkan, menghapus data kelola user.

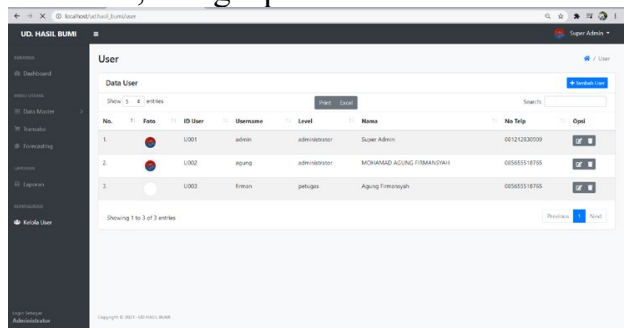

Gambar 11. Halaman Data Kelola User

\subsection{Perhitungan Metode Trend Moment}

Dalam perhitungan Metode Trend Moment penulis mengambil data pada tahun 2018-2019 pada
UD. Hasil Bumi. Data yang diambil adalah data transaksi penjualan yang terjadi pada UD. Hasil Bumi.

\subsection{Semen Gresik}

Pada Tabel 1 menunjukkan data penjualan setiap bulan pada jenis barang semen gresik, periode waktu yang digunakan untuk memprediksi penjualan yang akan datang adalah pada bulan Januari tahun 2018 sampai Bulan Desember tahun 2019.

Tabel 1. Penjualan semen gresik

\begin{tabular}{|l|l|}
\hline $\begin{array}{c}\text { Periode Penjualan } \\
\text { Data aktual }\end{array}$ & $\begin{array}{c}\text { Data Aktual } \\
\text { Penjualan (Y) }\end{array}$ \\
\hline Januari - 2018 & 55 \\
\hline Februari - 2018 & 45 \\
\hline Maret - 2018 & 20 \\
\hline April - 2018 & 19 \\
\hline Mei - 2018 & 10 \\
\hline Juni - 2018 & 18 \\
\hline Juli - 2018 & 31 \\
\hline Agustus - 2018 & 10 \\
\hline September - 2018 & 17 \\
\hline Oktober - 2018 & 12 \\
\hline November - 2018 & 14 \\
\hline Desember - 2018 & 19 \\
\hline Januari - 2019 & 100 \\
\hline Februari - 2019 & 77 \\
\hline Maret - 2019 & 77 \\
\hline April - 2019 & 59 \\
\hline Mei - 2019 & 16 \\
\hline Juni - 2019 & 22 \\
\hline Juli - 2019 & 45 \\
\hline Agustus - 2019 & 29 \\
\hline September - 2019 & 40 \\
\hline Oktober - 2019 & 23 \\
\hline November - 2019 & 19 \\
\hline Desember - 2019 & 47 \\
\hline
\end{tabular}

Berikutnya Tabel 2 menunjukkan perhitungan Forecasting penjualan dengan metode Trend Moment.

Tabel 2. Tabel Forecasting semen gresik

\begin{tabular}{|l|l|l|l|l|}
\hline $\begin{array}{c}\text { Periode } \\
\text { Penjualan Data } \\
\text { aktual }\end{array}$ & $\begin{array}{c}\text { Data Aktual } \\
\text { Penjualan (Y) }\end{array}$ & Waktu (X) & XY & $\mathbf{X}^{\wedge} \mathbf{2}$ \\
\hline Januari - 2018 & 55 & 0 & 0 & 0 \\
\hline Februari - 2018 & 45 & 1 & 45 & 1 \\
\hline Maret - 2018 & 20 & 2 & 40 & 4 \\
\hline April - 2018 & 19 & 3 & 57 & 9 \\
\hline Mei - 2018 & 10 & 4 & 40 & 16 \\
\hline Juni - 2018 & 18 & 5 & 90 & 25 \\
\hline Juli - 2018 & 31 & 6 & 186 & 36 \\
\hline Agustus - 2018 & 10 & 7 & 70 & 49 \\
\hline September - 2018 & 17 & 8 & 136 & 64 \\
\hline Oktober - 2018 & 12 & 9 & 108 & 81 \\
\hline November - 2018 & 14 & 10 & 140 & 100 \\
\hline Desember - 2018 & 19 & 11 & 209 & 121 \\
\hline Januari - 2019 & 100 & 12 & 1200 & 144 \\
\hline Februari - 2019 & 77 & 13 & 1001 & 169 \\
\hline Maret - 2019 & 77 & 14 & 1078 & 196 \\
\hline April - 2019 & 59 & 15 & 885 & 225 \\
\hline Mei - 2019 & 16 & 16 & 256 & 256 \\
\hline Juni - 2019 & 22 & 17 & 374 & 289 \\
\hline Juli - 2019 & 45 & 18 & 810 & 324 \\
\hline Agustus - 2019 & 29 & 19 & 551 & 361 \\
\hline September - 2019 & 40 & 20 & 800 & 400 \\
\hline Oktober - 2019 & 23 & 21 & 483 & 441 \\
\hline November - 2019 & 19 & 22 & 418 & 484 \\
\hline Desember - 2019 & 47 & 23 & 1081 & 529 \\
\hline Total & 824 & 276 & 10085 & 4324 \\
\hline & & & \\
\hline
\end{tabular}

Dari data penjualan toko UD. Hasil Bumi pada barang semen gresik diatas, pada Tabel 3 ditentukan nilai hasil prediksi pada bulan Januari tahun 2020 sampai Desember 2021 menggunakan metode Trend Moment dengan rumus persamaan $\hat{Y}=a+b(X)$. Untuk mendapatkan nilai hasil prediksi $\hat{Y}$, ditentukan 
terlebih dahulu rumus persamaan $\mathrm{b}$ dan rumus persamaan a dengan rumus sebagai berikut : $b=\frac{n(\mathrm{EXY})-(\mathrm{zX})(\mathrm{EY})}{n(\mathrm{EX})-(\mathrm{EX})^{2}}=\frac{24(10085)-(276)(824)}{24(4324)-(76176)^{2}}=0.506086957$ $a=\frac{E Y-b(E X)}{n}=\frac{824-0.506086957(276)}{24}=28.51333333$

Setelah mendapatkan nilai persamaan a dan nilai persamaan b, maka nilai hasil Forecasting setiap bulan dari bulan Januari 2020 sampai bulan Desember 2021 dapat di hitung pada Tabel 3. Hitung Forecasting semen gresik berikut

Tabel 3. Hitung Forecasting semen gresik

\begin{tabular}{|c|c|c|}
\hline Periode & \multicolumn{2}{|c|}{ Data Hasil Forecasting Penjualan $\left(\mathbf{Y}^{\prime}=\mathbf{a}+\mathbf{b}(\mathbf{x})\right)$} \\
\hline Januari - 2020 & $P=$ EFG & 40.65942029 \\
\hline Februari - 2020 & 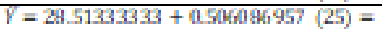 & 41.16550725 \\
\hline Maret - 2020 & 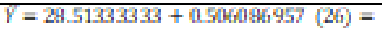 & 41.6715942 \\
\hline April - 2020 & 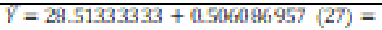 & 42.17768116 \\
\hline Mei - 2020 & 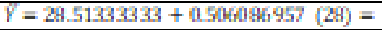 & 42.68376812 \\
\hline Juni -2020 & 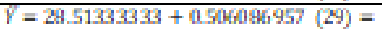 & 43.18985507 \\
\hline Juli -2020 & 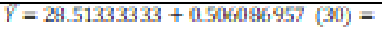 & 43.69594203 \\
\hline Agustus -2020 & 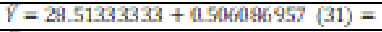 & 44.20202899 \\
\hline September -2020 & 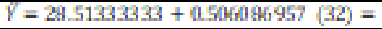 & 44.70811594 \\
\hline Oktober -2020 & 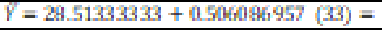 & 45.2142029 \\
\hline November -2020 & 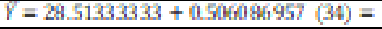 & 45.72028986 \\
\hline Desember -2020 & 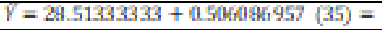 & 46.22637681 \\
\hline Januari -2021 & 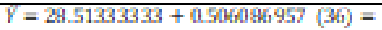 & 46.73246377 \\
\hline Februari -2021 & 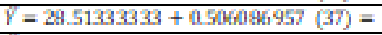 & 47.23855072 \\
\hline Maret -2021 & 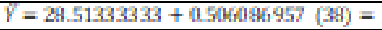 & 47.74463768 \\
\hline April-2021 & 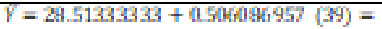 & 48.25072464 \\
\hline Mei-2021 & 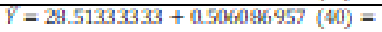 & 48.75681159 \\
\hline Juni -2021 & 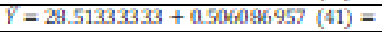 & 49.26289855 \\
\hline Juli -2021 & 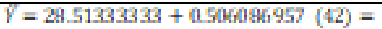 & 49.76898551 \\
\hline Agustus -2021 & 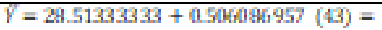 & 50.27507246 \\
\hline September -2021 & 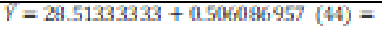 & 50.78115942 \\
\hline Oktober -2021 & 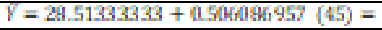 & 51.28724638 \\
\hline November -2021 & 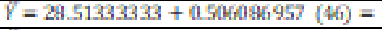 & 51.79333333 \\
\hline Desember - 2021 & 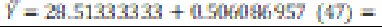 & 9 \\
\hline
\end{tabular}

Hasil Forecasting dapat dilihat pada Tabel 3. Hitung Forecasting semen gresik. Selanjutnya menghitung \% error dengan rumus sebagai berikut :

$$
\text { \%error }=\left|\frac{Y-\bar{Y}}{Y}\right| x 100
$$

Dimana Variabel :

$$
\begin{array}{ll}
\hat{Y} & : \text { Data hasil Forecasting penjualan } \\
\mathrm{Y} & \text { : Data penjualan aktual }
\end{array}
$$

ob emor $=\left|\frac{103-40.65942029}{103}\right| x 100=60.52483467$

\begin{tabular}{|c|c|c|c|c|c|}
\hline $\begin{array}{c}\text { Periode } \\
\text { Penjualan } \\
\text { Data } \\
\text { aktual }\end{array}$ & $\begin{array}{c}\text { Data } \\
\text { Aktual } \\
\text { Penjualan } \\
\text { (Y) }\end{array}$ & $\begin{array}{c}\text { Periode } \\
\text { Forecasting }\end{array}$ & $\begin{array}{l}\text { Data Hasil } \\
\text { Forecasting } \\
\text { Penjualan }\end{array}$ & Error & $\%$ Error \\
\hline $\begin{array}{l}\text { Januari - } \\
2020\end{array}$ & 103 & $\begin{array}{l}\text { Januari - } \\
2020 \\
\end{array}$ & 40.65942029 & 62.34057971 & 60.52483467 \\
\hline $\begin{array}{l}\text { Februari - } \\
2020\end{array}$ & 45 & $\begin{array}{l}\text { Februari - } \\
2020\end{array}$ & 41.16550725 & 3.834492754 & 8.521095008 \\
\hline $\begin{array}{l}\text { Maret - } \\
2020\end{array}$ & 100 & $\begin{array}{l}\text { Maret - } \\
2020 \\
\end{array}$ & 41.6715942 & 58.3284058 & 58.3284058 \\
\hline $\begin{array}{l}\text { April - } \\
2020\end{array}$ & 77 & April - 2020 & 42.17768116 & 34.82231884 & 45.2237907 \\
\hline Mei - 2020 & 17 & Mei - 2020 & 42.68376812 & 25.68376812 & 151.0809889 \\
\hline Juni -2020 & 60 & Juni -2020 & 43.18985507 & 16.81014493 & 28.01690821 \\
\hline Juli - 2020 & 53 & Juli - 2020 & 43.69594203 & 9.304057971 & 17.55482636 \\
\hline $\begin{array}{l}\text { Agustus - } \\
2020\end{array}$ & 88 & $\begin{array}{l}\text { Agustus - } \\
2020\end{array}$ & 44.20202899 & 43.79797101 & 49.77042161 \\
\hline $\begin{array}{l}\text { September } \\
-2020\end{array}$ & 59 & $\begin{array}{l}\text { September } \\
-2020\end{array}$ & 44.70811594 & 14.29188406 & 24.2235323 \\
\hline $\begin{array}{l}\text { Oktober - } \\
2020\end{array}$ & 43 & $\begin{array}{l}\text { Oktober - } \\
2020\end{array}$ & 45.2142029 & 2.214202899 & 5.149309066 \\
\hline $\begin{array}{l}\text { November } \\
-2020\end{array}$ & 78 & $\begin{array}{l}\text { November } \\
-2020\end{array}$ & 45.72028986 & 32.27971014 & 41.38424378 \\
\hline $\begin{array}{l}\text { Desember }- \\
2020\end{array}$ & 104 & $\begin{array}{l}\text { Desember - } \\
2020\end{array}$ & 46.22637681 & 57.77362319 & 55.55156076 \\
\hline & & Rata - rata $\%$ & & & $\begin{array}{l}45.444159 \\
\end{array}$ \\
\hline
\end{tabular}

Tabel 4 Persentase error data penjualan dengan data hasil prediksi semen gresik
Dari hasil Tabel 4 dapat di ketahui bahwasannya pada barang jenis semen gresik pengujian dari hasil rata - rata \% error perhitungan data aktual penjualan dengan data hasil Forecasting adalah 45.44415976 $\%$

Tabel 5. Model summary semen gresik

\begin{tabular}{|l|r|}
\hline \multicolumn{2}{|c|}{ SUMMARY OUTPUT } \\
\hline \multicolumn{2}{|c|}{ Regression Statistics } \\
\hline Multiple R & 0.247761455 \\
\hline R Square & 0.061385738 \\
\hline Adjusted R Square & -0.042904735 \\
\hline Standard Error & 26.9682005 \\
\hline Observations & 11 \\
\hline
\end{tabular}

Dari hasil tabel model summary pada barang semen gresik diatas dapat di ketahui bahwa nilai Multiple R sebesar 0.247761455, nilai R Square sebesar 0.061385738, dan nilai Adjusted R Square sebesar -0.042904735 .

\subsection{Rata - rata persentase error keseluruhan}

Hasil dari pengujian rata - rata persentase error keseluruhan dari jenis barang bahan bangunan seperti semen gresik, semen tiga roda, pasir lumajang, pasir biasa, batu pecah, batu krikil, bata ringan, besi 6", besi 8 ", besi 10", besi 12 " dan asbes sebagai berikut

Tabel 5. Rata - rata persentase error keseluruhan

\begin{tabular}{|l|l|}
\hline \multicolumn{1}{|c|}{ Jenis Barang } & \multicolumn{1}{c|}{$\begin{array}{c}\text { Rata - rata Persentase } \\
\text { Error \% (Perbarang) }\end{array}$} \\
\hline Semen Gresik & 45.44415976 \\
\hline Semen Tiga Roda & 38.99706294 \\
\hline Pasir Lumajang & 38.17777505 \\
\hline Pasir Biasa & 30.01658671 \\
\hline Batu Pecah & 45.66793085 \\
\hline Batu Krikil & 30.52744633 \\
\hline Bata Ringan & 16.04416206 \\
\hline Besi 6 & 34.6546565 \\
\hline Besi 8 & 39.15431383 \\
\hline Besi 10 & 32.80662068 \\
\hline Besi 12 & 45.92092538 \\
\hline Asbes & 44.04084888 \\
\hline $\begin{array}{l}\text { Rata - rata persentase } \\
\text { error keseluruhan }\end{array}$ & 36.78770742 \\
\hline
\end{tabular}

Dari hasil Tabel 5 dapat di ketahui hasil pengujian rata - rata persentase error pada hasil Forecasting penjualan bahan bangunan di UD. Hasil Bumi adalah $36.78770742 \%$.

\section{KESIMPULAN DAN SARAN}

\subsection{Kesimpulan}

Kesimpulan yang dapat penulis paparkan setelah melakukan peracangan prediksi penjualan bahan bangunan antara lain yaitu:

1. Penerapan metode Trend Moment pada aplikasi Forecasting penjualan bahan bangunan (studi kasus di UD. Hasil Bumi) berhasil diterapkan ke dalam sistem, sehingga sistem dapat memprediksi penjualan diwaktu yang akan datang dari hasil perhitungan dengan menggunakan data penjualan di masa lalu. 
2. Berdasarkan hasil dari perhitungan pengujian rata - rata persentase error pada hasil Forecasting penjualan bahan bangunan keseluruhan di UD. Hasil Bumi adalah 36.78770742\%.

3. Berdasarkan hasil pengujian metode Black-Box aplikasi Forecasting penjualan bahan bangunan menggunakan metode Trend Moment (studi kasus di UD. Hasil Bumi) dapat dijalankan sesuai luaran yang diharapkan dengan baik.

\subsection{Saran}

Untuk pengembangan aplikasi yang lebih baik, ada beberapa saran pada aplikasi Forecasting penjualan bahan bangunan menggunakan metode Trend Moment berbasis web yaitu:

1. Penelitian Aplikasi prediksi penjualan bahan bangunan di UD. Hasil Bumi diharapkan adanya pengembangan sistem ini menjadi berbasis mobile.

2. Penelitian selanjutnya bisa dikembangkan dengan membandingkan metode lain seperti metode Exponential Smoothing.

\section{DAFTAR PUSTAKA}

[1] Albert Verasius Dian Sano. (2019). Definisi, Karakteristik, Dan Manfaat Data Mining Seri Data Mining for Business Intelligence (2). Binus University Computer Science, Januari 2019.

[2] Batubara, F. A. (2015). Perancangan Website Pada PT. Ratu Enim Palembang. Jurnal Ilmu Pengetahuan Dan Teknologi Terapan" Reintek"(Rekayasa Inovasi Teknologi), 7(1).

[3] Frans, J. A., Orisa, M., \& Wibowo, S. A. (2020). Prediksi Penjualan Kayu Lapis Di Cv Diato Wood St 99999 rejahtera Dengan Metode Trend Moment Berbasis Web. JATI (Jurnal Mahasiswa Teknik Informatika), 4(2), 183-190.

[4] Fuad, N., \& Sulistiono, E. (2016). Prediksi Penjualan Kerudung Rabbani di Griya Muslim Store Dukun Gresik dengan Trend Moment.

[5] Ilyas, I., Marisa, F., \& Purnomo, D. (2018). Implementasi Metode Trend Moment (Peramalan) Mahasiswa Baru Universitas
Widyagama Malang. JOINTECS (Journal of Information Technology and Computer Science), 3(2), 69-74.

[6] Istiono, W., \& Hijrah, H. (2016). Pengembangan Sistem Aplikasi Penilaian dengan Pendekatan MVC dan Menggunakan Bahasa PHP dengan Framework Codeigniter dan Database MYSQL pada Pahoa College Indonesia. Jurnal TICom, 5(1), 93757.

[7] Jana, P. (2016). Aplikasi Triple Exponential Smoothing Untuk Forecasting Jumlah Penduduk Miskin. Jurnal Derivat: Jurnal Matematika dan Pendidikan Matematika, 3(2), 76-82.

[8] Niswatin, R. K. (2015). Sistem Pendukung Keputusan Peramalan Produksi Air Minum Menggunakan Metode Trend Moment. Simetris: Jurnal Teknik Mesin, Elektro dan Ilmu Komputer, 6(2), 337-344.

[9] Santi, I. H., \& Saputra, A. R. (2019). Prediksi Jumlah Permintaan Telur Ayam Menggunakan Metode Trend Moment. Inform. Mulawarman J. Ilm. Ilmu Komput, 14(2), 111.

[10] Sovia, R., \& Febio, J. (2017). Membangun Aplikasi E-Library Menggunakan Html, Php Script, Dan Mysql Database. Jurnal Processor, 6(2).

[11] Sumaryono, R., \& Mahardhika, S. T. I. E. (2014). Penerapan Metode Trend Moment dalam Forecast Penjualan Beton Readymix di PT. X Mojokerto. Jurnal Media Mahardika. (Online), 13(1), 51-57.

[12] Susanto, Sani dan Dedy Suryadi. 2010. Pengantar Data mining menggali pengetahuan dari bongkahan data. Yogyakarta: Andi.

[13] Yanto, I. R., Farida, I. N., \& Bilal, M. (2018). Penerapan Metode Trend Moment Dalam Forecasting Penjualan Kasur Busa Di Mebel Anugerah Cukir Jombang. J. Chem. Inf. Model, 53(9), 1689-1699. 